\title{
Recovery of sperm after epididymal refrigeration from domestic cats using ACP-117c and Tris extenders
}

[Recuperação de espermatozoides após refrigeração do epidídimo de gatos domésticos utilizando os diluidores ACP-117c e Tris]

D.B.C. Lima, T.F.P. Silva, A. Aquino Cortez, J.N. Pinto, F.F. Magalhães, B.N. Caldini, L.D.M. Silva*

Universidade Estadual do Ceará - UECE - Fortaleza, CE

\begin{abstract}
We aimed to compare fresh sperm and sperm cooled to $4^{\circ} \mathrm{C}$ that had been recovered from the epididymides of cats using powdered coconut water (ACP-117c) and Tris extenders. Sixty epididymides were divided into 6 groups: 10 fresh epididymides were recovered using Tris (T0h); 10 were kept at $4^{\circ} \mathrm{C} / 2 \mathrm{~h}$ and recovered using Tris (T2h); 10 were kept at $4^{\circ} \mathrm{C} / 4 \mathrm{~h}$ and recovered using Tris (T4h); 10 fresh were recovered using ACP-117c (A0h); 10 were kept at $4^{\circ} \mathrm{C} / 2 \mathrm{~h}$ and recovered using ACP-117c (A2h), and 10 were kept at $4^{\circ} \mathrm{C} / 4 \mathrm{~h}$ and recovered using $\mathrm{ACP}-117 \mathrm{c}$ (A4h). The testis-epididymis complexes (TEC) control were not cooled. The others were cooled at $4^{\circ} \mathrm{C}$ for 2 or $4 \mathrm{~h}$. The epididymis was separated and the sperm was recovered by the modified flotation method. Sperm kinetic parameters were evaluated by a computer-system analysis, and vigor, viability, concentration, membrane function and morphology of the sperm were assessed under a light microscope. The progressive motility with ACP-117c declined after $2 \mathrm{~h}$ of cooling, but did not differ between fresh and $4 \mathrm{~h}$. The vigor and membrane function were higher in A4h than A0h. The vigor at T2h and T4h were decreased compared to T0h. T0h was higher than A0h for vigor and sperm membrane function. However, after $4 \mathrm{~h}$ of cooling, ACP-117c maintained a higher percentage of living cells. Feline epididymal sperm quality can be maintained to the degree necessary for artificial breeding programs following cooling and ACP-117c may be successfully used to recover cat sperm that have been cooled for up to $4 \mathrm{~h}$.
\end{abstract}

Keywords: cat, epididymal spermatozoa, cooling, powdered coconut water

\section{RESUMO}

Objetivou-se comparar a qualidade de espermatozoides recuperados a fresco e após refrigeração a $4^{\circ} \mathrm{C}$ do epidídimo de gatos domésticos utilizando-se os diluidores ACP-117c e Tris. Sessenta epidídimos foram distribuídos em seis grupos: 10 epidídimos a fresco com o Tris (TOh), 10 a $4^{\circ} \mathrm{C} / 2 \mathrm{~h}$ e recuperados com Tris (T2h), 10 a $4^{\circ} \mathrm{C} / 4 \mathrm{~h}$ e recuperados com Tris (T4h), 10 epidídimos a fresco com o ACP-117c (A0h), 10 a $4{ }^{\circ} \mathrm{C} / 2 \mathrm{~h}$ e recuperados com $\mathrm{ACP}-117 \mathrm{c}$ (A2h), 10 a $4^{\circ} \mathrm{C} / 4 \mathrm{~h}$ e recuperados com $\mathrm{ACP}-117 \mathrm{c}$ (A4h). Os complexos testículo-epidídimo (CTE) do controle não foram refrigerados. Os outros foram refrigerados $a 4^{\circ} \mathrm{C}$ durante duas e quatro horas. Os epidídimos foram separados das demais estruturas, $e$ os espermatozoides recuperados pela técnica de flutuação modificada. Os parâmetros cinéticos foram avaliados em um sistema computadorizado, e o vigor, a viabilidade, a concentração, a funcionalidade de membrana e a morfologia celular foram avaliados em microscopia de luz. A motilidade progressiva com ACP-117c declinou após duas horas de refrigeração, mas não diferiu entre a recuperação a fresco $e$ após refrigeração por quatro horas. Vigor e integridade funcional da membrana celular foram significativamente superiores no grupo A4h em comparação ao A0h. O vigor espermático em T2h e T4h reduziu significativamente em comparação com T0h. T0h foi significativamente superior ao A0h quanto aos parâmetros de vigor e integridade funcional da membrana espermática, entretanto, após quatro

Recebido em 5 de agosto de 2015

Aceito em 11 de fevereiro de 2016

* Autor para correspondência (corresponding author)

E-mail: lucia.daniel.machado@hotmail.com 
horas de refrigeração, o ACP-117c apresentou um maior percentual de células vivas. Os espermatozoides epididimários de felinos domésticos conseguem manter a qualidade necessária para serem utilizados em programas de reprodução artificial após serem refrigerados e recuperados por meio da técnica de flutuação modificada, e o diluidor ACP-117c pode ser utilizado com sucesso para recuperação de células espermáticas refrigeradas de gatos por até quatro horas.

Palavras-chave: gato doméstico, espermatozoide epididimário, refrigeração, água de coco em pó

\section{INTRODUCTION}

The biomethods used in the breeding of domestic cats have advanced significantly in recent years, and the recovery of sperm from the epididymides of these animals is a possible approach to preserve animal fertility and create new opportunities for artificial breeding programs (Vernocchi et al., 2014). Of the 36 species of cats that currently exist, the domestic cat is the only one that is not endangered, so it is an appropriate experimental model for other cat species (Magalhães et al., 2012). The application of technological advances in breeding can improve the genetic characteristics of domestic cats and contribute to the conservation of endangered wild cats (Villaverde et al., 2009).

The collection of epididymal sperm is a key for assisted reproduction because it enables the storage of gametes from animals of high genetic value that have died or required castration (Mota Filho et al., 2014). These sperm manage to maintain their capacity for fertilization after collection and may be cooled for later use. However, sperm quality may decline during the cooling period, so there is a need for studies that seek to establish the optimal cooling time for cat epididymal sperm (Tebet et al., 2006).

The cooling process promotes decreased sperm metabolism, which extends the viability and fertilization capacity of sperm cells, but cooling also affects the quality of the semen. Thus, cryoinjury to sperm cells during preservation at low temperatures is still an obstacle in the field of assisted reproduction. Efficient and effective protocols for cooling semen have not yet been developed despite the progress made in this field of research (Hermansson and Axnér, 2007; Gosden, 2011).

The use of semen extenders can create an environment favorable to sperm survival following the cooling period and thus allow for the use of cooled sperm in artificial insemination programs. The Tris (hydroxymethyl aminomethane-based) extender has successfully been used in the cryopreservation of sperm from domestic carnivores and serves as a model for studies of new extenders. When combined with a source of energy, such as fructose, and a natural antioxidant, such as citric acid, the Tris buffer solution has shown better results than other semen extenders (Silva et al., 2002).

The use of alternative extenders for cooling animal semen, such as coconut water, has shown promising results, and the ability of coconut water to preserve the characteristics of in vivo and in vitro sperm following cryopreservation has been demonstrated in studies of several species, namely fish (Viveiros et al., 2010), dogs (Uchoa et al., 2012), stallions, bulls, goats, boars (Barros and Toniolli, 2011), and even wild species, including the capuchin monkey (Oliveira et al., 2011) and the common agouti (Silva et al., 2011).

However, studies that assess the use of powdered coconut water for the cryopreservation of domestic cat sperm are incipient, but new research is driving the use of the medium as an alternative for commercial farms and wild cat conservation programs (Silva et al., 2012; Emerenciano et al., 2013).

Thus, this study aimed to compare the kinetic, vital, functional and morphological parameters of epididymal sperm recovered that was cooled for 0,2 or 4 hours and diluted in powdered coconut water-based extender (ACP-117c) to that cooled and diluted in Tris.

\section{MATERIALS AND METHODS}

This experiment was approved by the Animal Ethics Committee of Ceará State University (Universidade Estadual do Ceará; No. 4627370/2014) and it was performed at the Laboratory of Carnivore Reproduction located in Fortaleza city/Ceará $\left(3^{\circ} 44^{\prime}\right.$ south latitude and 
$38^{\circ} 34^{\prime}$ west longitude). This location presents semi-humid equatorial weather, approximately 12 hours of natural light daily throughout the year, and mean monthly temperature, rain and relative humidity of $28.6^{\circ} \mathrm{C}, 12.0 \mathrm{~mm}$ and $80 \%$, respectively. Thirty pubescent mongrel male cats, clinically healthy, that weighed from 2.5 to $5 \mathrm{~kg}$, ranging from one to five years old, with no history of reproductive diseases were used in this study. All animals came from private owners who wanted to castrate them.

The ACP-117c extender was prepared according to manufacturer's recommendations (ACPBiotechnology, Fortaleza-CE, Brazil). One package of ACP-117c weighing $12 \mathrm{~g}$ is reconstituted in $50 \mathrm{ml}$ of distilled water, yielding a solution with an osmolarity of $295 \mathrm{mOsm} / \mathrm{L}$ and $\mathrm{pH}$ 7.4. The Tris extender was composed of $3.028 \mathrm{~g}$ Tris-hydroxymethyl-aminomethane, $1.78 \mathrm{~g}$ of monohydrated citric acid and $1.25 \mathrm{~g} \mathrm{D}$ fructose dissolved in $100 \mathrm{ml}$ distilled water, with a final osmolarity of $295 \mathrm{mOsm} / \mathrm{L}$ and $\mathrm{pH}$ 6.6. The Tris extender was used as a control, and ACP-117c was used as a test extender. A total of 60 epididymides were collected. Six experimental groups were compared as follows: fresh sperm from 10 epididymides were recovered using Tris (T0h); 10 epididymides were cooled at $4^{\circ} \mathrm{C} / 2$ hours, and the sperm were subsequently recovered using Tris (T2h); 10 epididymides were cooled at $4^{\circ} \mathrm{C} / 4$ hours, and the sperm were subsequently recovered using Tris (T4h); 10 epididymides were part of the group of fresh sperm recovered using ACP-117c (A0h); 10 epididymides were cooled at $4^{\circ} \mathrm{C} / 2$ hours, and the sperm were subsequently recovered using ACP-117c (A2h); 10 epididymides were cooled at $4^{\circ} \mathrm{C} / 4$ hours, and the sperm were subsequently recovered using ACP-117c (A4h). In total, there were 10 epididymides for each extender and cooling time (Figure 1).

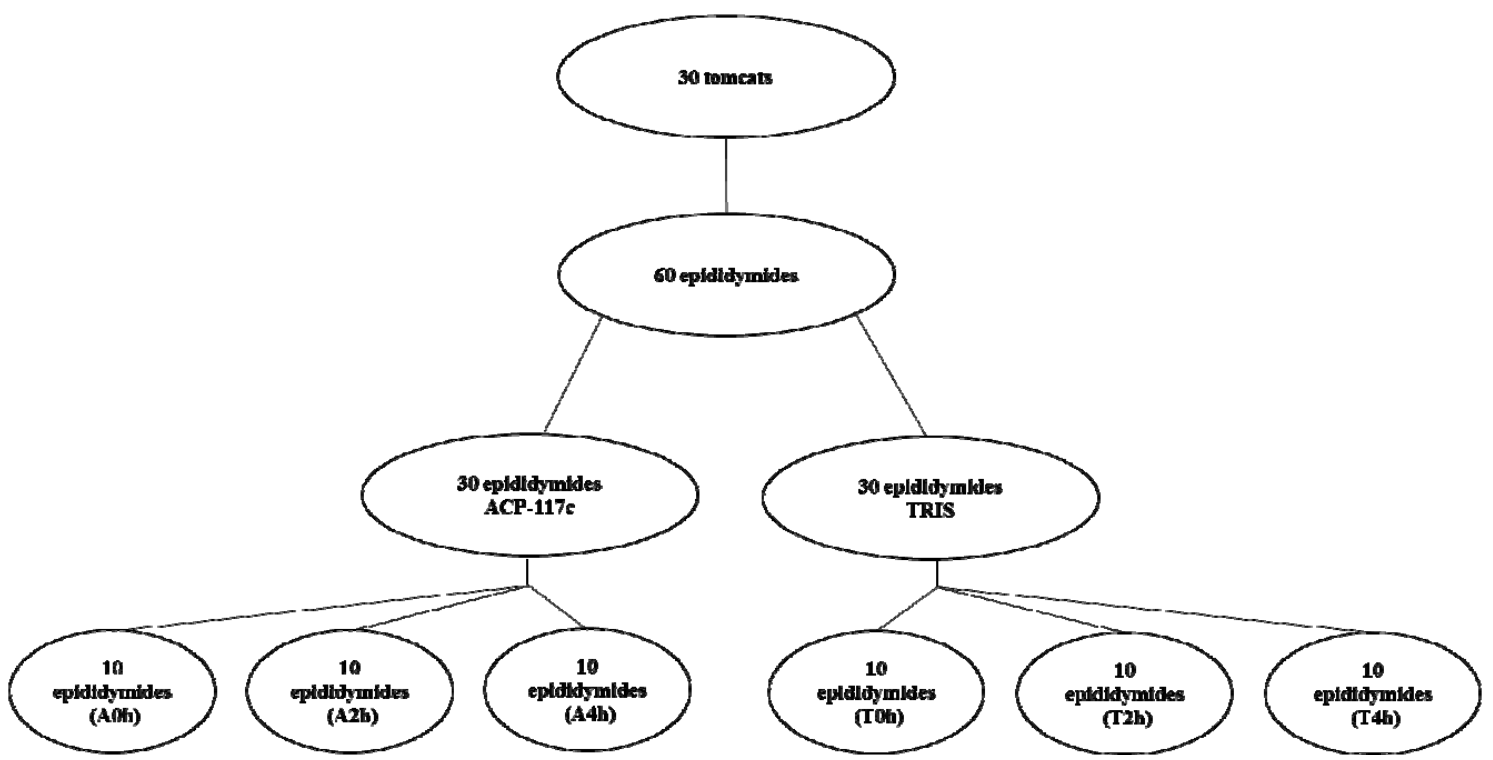

Figure 1. Distribution of experimental groups according to type of extender and cooling time of epididymides.

During the preoperative period, the study animals were subjected to a general clinical examination and macroscopic evaluation of their reproductive organs through visualization and palpation. Only clinically healthy animals without injury to their external reproductive organs and with normal testicular symmetry and consistency were used. Cats deemed suitable for the study were food fasted for 12 hours and water fasted for 6 hours before undergoing the bilateral orchiectomy procedure. The preoperative protocol consisted of prophylactic antibiotic therapy with enrofloxacin $(5 \mathrm{mg} / \mathrm{kg}$ injected intramuscularly (IM)), the non-steroidal, anti-inflammatory drug meloxicam $(0.2 \mathrm{mg} / \mathrm{kg}$ IM), and tramadol hydrochloride ( $2 \mathrm{mg} / \mathrm{kg} \mathrm{IM})$ for preemptive analgesia (Viana, 2007). Acepromazine $(0.2 \mathrm{mg} / \mathrm{kg} \mathrm{IM})$ and xylazine 
hydrochloride $(0.8 \mathrm{mg} / \mathrm{kg}$, IM) were used as preanesthetic medications (PAM) (Cortopassi and Fantoni, 2009). Fifteen minutes after administering the PAM, anesthesia was induced and maintained using intravenous ketamine hydrochloride $(8 \mathrm{mg} / \mathrm{kg})$ and diazepam $(1 \mathrm{mg} / \mathrm{kg})$ by applying half of the initial dose for anesthetic reinforcement when required (Valadão, 2009). The animals were subsequently subjected to a bilateral orchiectomy (Boothe, 2007), and the left and right testis-epididymis complexes (TEC) were collected. Following recovery from the anesthesia, the animals were discharged from the hospital, and the owners received recommendations for post-surgical therapy.

Following collection, the TEC were placed in beakers and immersed in $0.9 \%$ saline solution of a total volume of $30 \mathrm{ml}$ and taken to the processing room within 3 minutes. The TEC from the sperm groups that were recovered fresh were immediately processed, and the TEC from the other groups were cooled at $4^{\circ} \mathrm{C}$ for 2 or 4 hours. The TEC were randomly distributed in experimental groups. The recovery of epididymal sperm was performed using the epididymal cauda and the proximal region of deferent duct by the modified flotation method (Emerenciano et al., 2013). The connective tissue covering the epididymis was removed, and the contours of the epididymal duct were dissected using a scalpel, and following the dissection, the exterior of the epididymis was washed using a preheated saline solution $\left(37^{\circ} \mathrm{C}\right)$. After the external washing of the epididymis, each entire epididymal duct was placed in Petri dishes that had also been preheated $\left(37^{\circ} \mathrm{C}\right)$. Unlike the traditional flotation method, in order to improve sperm recovery, thrice $1 \mathrm{ml}$ quantities of air were immediately injected into the epididymal lumen using an insulin syringe coupled to a $30 \mathrm{G}$ needle, and $0.5 \mathrm{ml}$ of extender, either Tris or ACP-117c, was subsequently added inside the epididymis. Finally, the epididymal cauda and the proximal region of deferent duct were divided into small fragments using two scalpel blades and left standing in the Petri dish for 1 minute to promote contact between the sperm and the extender. Aliquots of the resulting solution were used for the evaluation of the sperm using an automatic pipette.

For computer analysis, $10 \mu \mathrm{l}$ of the dilution was evaluated in a phase contrast microscope connected to a video camera adapted to the computer-system analysis (CASA) using the Sperm Class Analyser ${ }^{\circledR}$ software (SCA Microptic SL, version 5.3.0.1). The following spermatic parameters were analyzed: total and progressive motility, average path velocity (VAP), curvilinear velocity (VCL), straight line velocity (VSL) linearity index (LIN) and straightness index (STR), amplitude of lateral head displacement (ALH) and beat cross frequency (BCF) (Mota Filho et al., 2014). The following parameters of the epididymal sperm were evaluated under a light microscope: vigor, viability, concentration, membrane function and morphology.

A $10 \mu 1$ aliquot of the solution was used to assess the total motility and vigor of the epididymal sperm. The analysis was performed at 100x magnification. Sperm vigor was expressed using a progressive scale from 0 (no movement) to 5 (vigorous, straight and progressive movement). The percentage of live and dead sperm was calculated by counting 100 cells per slide after preparing a smear using $5 \mu \mathrm{l}$ of solution and $5 \mu \mathrm{l}$ of bromophenol blue dye at 400x magnification. Sperm concentration was expressed in millions per $\mathrm{ml}$ (sperm $\left.\times 10^{6} / \mathrm{ml}\right)$ and calculated by diluting $5 \mu \mathrm{l}$ of solution in $1 \mathrm{ml}$ of $1 \%$ formolized saline solution and counting the number of cells in a Neubauer chamber at $400 x$ magnification. Sperm membrane function was evaluated by the hypoosmotic test using distilled water as the hypoosmotic solution at a ratio of $10 \mu \mathrm{l}$ of solution to $90 \mu \mathrm{l}$ of distilled water. One hundred cells were evaluated at 400x magnification after 30 minutes in a water bath. Coil-tailed sperm were considered functional. Rose bengal staining was used to assess sperm morphology. Smears were prepared using $10 \mu \mathrm{l}$ of solution diluted in $150 \mu \mathrm{l}$ of dye, and 100 cells were assessed at 1000x magnification and classified as normal or abnormal (primary or secondary defects).

The recorded data were expressed as means and standard deviations and analyzed using Assistat software version 7.7 beta. The data were subjected to the Shapiro-Wilk normality test, and the percentages were subsequently angularly arcsine transformed. The resulting ratios for kinetic parameters, viability, membrane function and morphology were subjected to analysis of variance (ANOVA) followed by Tukey's test to compare the cooling times, and the Student's t 
test was applied to compare the extenders. The sperm vigor data were assessed using the MannWhitney test. Results were considered significant when $\mathrm{P}<0.05$.

\section{RESULTS}

The modified flotation method enabled the recovery of epididymal sperm from all animals involved in the experiment regardless of the extender used. The mean sperm concentration from all of the animals was $294.83 \pm 304.14 \times 10^{6}$ $\mathrm{sperm} / \mathrm{mL}$.
In computer analysis of the kinetic parameters, for ACP-117c, the fresh progressive motility was greater than the cool time of 2 hours; however, both do not differ from recovery after 4 hours of cooling. With regard to Tris, LIN and STR were inferior at 4 hours compared to cooling at 2 hours; however, both do not decline in relation to the fresh recovery sperm. After 2 hours of cooling, VCL with Tris was higher when compared to VCL with ACP 117c. The other parameters did not differ in the different cooling times for each extender, as well as the comparison between the extenders (Table 1).

Table 1. Mean \pm SD for the feline epididymal sperm parameters determined after cooling of epididymides for 0,2 or 4 hours and diluted in ACP-117c or Tris assessed by CASA. Average path velocity (VAP), curvilinear velocity (VCL), straight line velocity (VSL), linearity index (LIN), straightness index (STR), amplitude of lateral head displacement (ALH) and beat cross frequency (BCF)

\begin{tabular}{|c|c|c|c|c|c|c|}
\hline \multirow{3}{*}{$\begin{array}{l}\text { Epididymal sperm } \\
\text { parameters }\end{array}$} & \multicolumn{6}{|c|}{ Cooling time } \\
\hline & \multicolumn{2}{|c|}{0 hour } & \multicolumn{2}{|c|}{2 hours } & \multicolumn{2}{|c|}{4 hours } \\
\hline & ACP-117c & TRIS & ACP-117c & TRIS & ACP-117c & TRIS \\
\hline Total Motility (\%) & $56.40 \pm 43.34^{\mathrm{aA}}$ & $67.32 \pm 25.74^{\mathrm{aA}}$ & $39.57 \pm 33.24^{\mathrm{aA}}$ & $69.40 \pm 16.38^{\mathrm{aA}}$ & $71.52 \pm 18.12^{\mathrm{aA}}$ & $67.10 \pm 26.72^{\mathrm{aA}}$ \\
\hline Progressive Motility (\%) & $25.72 \pm 25.18^{\mathrm{aA}}$ & $12.79 \pm 13.79^{\mathrm{aA}}$ & $6.15 \pm 11.55^{\mathrm{bA}}$ & $8.37 \pm 9.91^{\mathrm{aA}}$ & $17.17 \pm 11.63^{\mathrm{abA}}$ & $12.28 \pm 22.36^{\mathrm{aA}}$ \\
\hline $\operatorname{VAP}(\mu \mathrm{m} / \mathrm{s})$ & $51.14 \pm 28.12^{\mathrm{aA}}$ & $47.15 \pm 16.31^{\mathrm{aA}}$ & $36.99 \pm 11.97^{\mathrm{aA}}$ & $39.39 \pm 8.90^{\mathrm{aA}}$ & $45.34 \pm 14.37^{\mathrm{aA}}$ & $37.88 \pm 16.05^{\mathrm{aA}}$ \\
\hline $\operatorname{VCL}(\mu \mathrm{m} / \mathrm{s})$ & $70.68 \pm 31.48^{\mathrm{aA}}$ & $86.55 \pm 24.86^{\mathrm{aA}}$ & $56.14 \pm 12.69^{\mathrm{aA}}$ & $69.97 \pm 16.68^{\mathrm{aB}}$ & $67.86 \pm 20.96^{\mathrm{aA}}$ & $70.64 \pm 27.70^{\mathrm{aA}}$ \\
\hline $\operatorname{VSL}(\mu \mathrm{m} / \mathrm{s})$ & $39.42 \pm 23.68^{\mathrm{aA}}$ & $33.75 \pm 9.77^{\mathrm{aA}}$ & $28.47 \pm 10.16^{\mathrm{aA}}$ & $31.18 \pm 3.47^{\mathrm{aA}}$ & $34.66 \pm 12.85^{\mathrm{aA}}$ & $26.50 \pm 12.12^{\mathrm{aA}}$ \\
\hline LIN (\%) & $54.58 \pm 16.51^{\mathrm{aA}}$ & $39.65 \pm 6.07^{\mathrm{abA}}$ & $50.95 \pm 15.29^{\mathrm{aA}}$ & $45.26 \pm 5.82^{\mathrm{aA}}$ & $45.64 \pm 19.01^{\mathrm{aA}}$ & $36.72 \pm 7.06^{\mathrm{bA}}$ \\
\hline STR (\%) & $76.20 \pm 9.18^{\mathrm{aA}}$ & $72.93 \pm 6.91^{\mathrm{abA}}$ & $76.35 \pm 10.24^{\mathrm{aA}}$ & $80.28 \pm 9.33^{\mathrm{aA}}$ & $73.40 \pm 8.42^{\mathrm{aA}}$ & $68.91 \pm 10.23^{\mathrm{bA}}$ \\
\hline $\mathrm{ALH}(\mu \mathrm{m})$ & $1.89 \pm 1.79^{\mathrm{aA}}$ & $3.94 \pm 2.35^{\mathrm{aA}}$ & $2.76 \pm 0.80^{\mathrm{aA}}$ & $1.88 \pm 2.66^{\mathrm{aA}}$ & $2.93 \pm 1.29^{\mathrm{aA}}$ & $3.52 \pm 1.90^{\mathrm{aA}}$ \\
\hline $\mathrm{BCF}(\mathrm{Hz})$ & $5.96 \pm 5.73^{\mathrm{aA}}$ & $11.03 \pm 6.25^{\mathrm{aA}}$ & $8.26 \pm 2.79^{\mathrm{aA}}$ & $7.74 \pm 10.94^{\mathrm{aA}}$ & $10.99 \pm 4.91^{\mathrm{aA}}$ & $9.06 \pm 6.22^{\mathrm{aA}}$ \\
\hline
\end{tabular}

Different lowercase letters within a row indicate statistically significant differences between the cooling times for each extender $(\mathrm{P}<0.05)$.

Different uppercase letters within a row indicate statistically significant differences between extenders for the different cooling times $(\mathrm{P}<0.05)$.

The sperm recovered from epididymides using the ACP-117c extender showed a significant improvement in the parameters of vigor and cell membrane functional integrity after 4 hours of cooling compared to sperm recovered fresh. The sperm recovered from epididymides using the Tris extender after 2 and 4 hours of cooling showed a significant decline only in the vigor compared to the sperm recovered at 0 hours (Table 2).

The Tris extender had significantly higher vigor and sperm membrane functional integrity than ACP-117c in freshly recovered sperm. However, ACP-117c recovered sperm had a higher percentage of living cells after 4 hours of cooling (Table 2).

Table 2. Mean \pm SD for the feline epididymal sperm parameters determined after cooling of epididymides for 0,2 or 4 hours and diluted in ACP-117c or Tris assessed

\begin{tabular}{|c|c|c|c|c|c|c|}
\hline \multirow{3}{*}{ Epididymal sperm parameters } & \multicolumn{6}{|c|}{ Cooling time } \\
\hline & \multicolumn{2}{|c|}{0 hour } & \multicolumn{2}{|c|}{2 hours } & \multicolumn{2}{|c|}{4 hours } \\
\hline & ACP-117c & TRIS & ACP-117c & TRIS & ACP-117c & TRIS \\
\hline Vigor (0-5) & $3.35 \pm 1.11 \mathrm{aA}$ & $4.70 \pm 0.42 \mathrm{aB}$ & $3.60 \pm 0.88 \mathrm{abA}$ & $3.90 \pm 0.84 \mathrm{bA}$ & $4.30 \pm 0.71 \mathrm{bA}$ & $3.85 \pm 0.94 \mathrm{bA}$ \\
\hline Sperm viability (\%) & $64.40 \pm 19.55 \mathrm{aA}$ & $66.70 \pm 22.93 \mathrm{aA}$ & $68.70 \pm 17.76 \mathrm{aA}$ & $54.70 \pm 19.89 \mathrm{aA}$ & $71.70 \pm 15.20 \mathrm{aA}$ & $53.20 \pm 17.78 \mathrm{aB}$ \\
\hline Memb. functional integrity (\%) & $58.60 \pm 17.82 \mathrm{aA}$ & $79.90 \pm 8.74 \mathrm{aB}$ & $67.00 \pm 17.17 \mathrm{abA}$ & $71.00 \pm 14.45 \mathrm{aA}$ & $76.00 \pm 11.01 \mathrm{bA}$ & $63.80 \pm 21.78 \mathrm{aA}$ \\
\hline Normal morphology (\%) & $77.50 \pm 8.30 \mathrm{aA}$ & $80.00 \pm 12.70 \mathrm{aA}$ & $73.10 \pm 10.95 \mathrm{aA}$ & $79.10 \pm 10.03 \mathrm{aA}$ & $76.80 \pm 10.24 \mathrm{aA}$ & $74.80 \pm 16.65 \mathrm{aA}$ \\
\hline Primary defects $(\%)$ & $5.10 \pm 5.40 \mathrm{aA}$ & $3.90 \pm 5.90 \mathrm{aA}$ & $2.40 \pm 1.90 \mathrm{aA}$ & $4.70 \pm 3.06 \mathrm{aA}$ & $2.40 \pm 3.37 \mathrm{aA}$ & $7.30 \pm 19.30 \mathrm{aA}$ \\
\hline Secondary defects (\%) & $17.40 \pm 8.13 \mathrm{aA}$ & $16.10 \pm 9.01 \mathrm{aA}$ & $24.50 \pm 11.27 \mathrm{aA}$ & $16.20 \pm 8.46 \mathrm{aA}$ & $20.80 \pm 11.11 \mathrm{aA}$ & $17.90 \pm 12.71 \mathrm{aA}$ \\
\hline
\end{tabular}

Different lowercase letters within a row indicate statistically significant differences between the cooling times for each extender $(\mathrm{P}<0.05)$.

Different uppercase letters within a row indicate statistically significant differences between extenders for the different cooling times $(\mathrm{P}<0.05)$. 


\section{DISCUSSION}

The use of a suitable collection method for the species being studied is required for the successful recovery and preservation of epididymal sperm (Mota Filho et al., 2014). Flotation is the method of choice for domestic cats, and it consists of separating the epididymis from the other structures of the male reproductive tract and subsequently fragmenting it. The resulting fragments are then mixed with an extender, and the sperm is recovered. The use of other collection methods is complicated by the anatomy of the cat epididymis as it is very small compared to that of other species (Emerenciano et al., 2013).

However, the retrograde flow method has been used in several species with rather satisfactory results. Following dissection of the epididymis, a cut is made close to the tail region, and the extender is then injected into the epididymal lumen and the content is expelled using a syringe filled with air. The sperm cells are then recovered (Monteiro et al., 2013; Pradiee et al., 2014).

In this study, the application of the flotation method with some modifications, including the injection of both air and extender in the epididymal lumen prior to fragmentation, enabled the collection of sperm with kinetic and morphological characteristics desirable for use in artificial insemination programs. Thus, the protocol used for the recovery of epididymal sperm in this study might be successfully applied to other cats and small species.

The large degree of individual variation in the sperm concentrations of the evaluated animals corroborates the results of previous studies (Axnér and Linde-Forsberg, 2003; Emerenciano et al., 2013). However, the sperm concentrations assessed in this study were much higher than those in other research studies that used the conventional flotation method. A study conducted in 2009 found a sperm concentration of $8.15 \times 10^{6} \mathrm{sperm} / \mathrm{ml}$ (Cocchia et al., 2009), which suggests that the modified flotation method directly affected the resulting ratio of sperm cells. This finding is significant for the establishment of germplasm banks for wild cats because the higher the sperm concentration, the greater the number of available insemination doses and the higher the breeding success of endangered cats (Martinez-Pastor et al., 2006).

In addition to the technique of sperm cell recovery from epididymides, in order for the cooling process to prolongue the viability and fertilizing capacity of these cells, it is necessary to consider the possibility of cell cryoinjury, which represents a major obstacle in epididymal sperm cooling process. There is wide variation in used protocols, which are often established in accordance with the practical experience of each study center. This fact contributes to the occurrence of different success rates in the experiments. It is noteworthy that there are no cooling protocols that can completely eliminate cell cryoinjury (Gosden, 2011). However, in order to ensure the future use of epididymal sperm in conservation programs of genetic material from endangered cats, refrigeration is an essential step that must be unraveled in each study.

In this context, in order to improve the cooling protocols and preservation of epididymal sperm cells, research involving the cooling time and different extender comparisons on refrigeration protocols will contribute to advances in reproductive biotechnologies applied to cats (Cocchia et al., 2009).

In this perspective, the use of powdered coconut water as a semen extender has proven to be a rather effective alternative for the preservation of important in vitro and in vivo sperm characteristics in several species (Nunes, 2010). That extender solution consists of several components required for the survival of sperm cells, including sugars, salts, vitamins, proteins and growth factors, namely, indole-3-acetic acid (IAA), an auxin that regulates cell growth and division in plants. The ability of the IAA present in coconut water to stimulate sperm motility has already been shown (Uchoa et al., 2002), and it also enables a higher ratio of living sperm cells when compared, for example, to pig sperm preserved by cooling. Pigs expressed higher fertilization rates in vitro in females inseminated with sperm supplemented with IAA (Barros and Toniolli, 2011).

This study was the first to cool the epididymis of domestic cats for up to 4 hours and recover the epididymal sperm using the ACP extender. The 
components of the ACP-117c extender, the IAA in particular, presumably contributed to the significant improvement in the sperm viability following the cooling period.

Unlike previously conducted studies, the total motility after dilution of fresh sperm cells recovered in Tris do not prove to be better than in coconut water (Emerenciano et al., 2013) and $\mathrm{ACP}-117 \mathrm{c}$ resulted in a higher percentage of living cells after 4 hours of cooling. This showed the ability of this extender to interact with the sperm while maintaining the integrity of the cells and protecting them against heat shock during recovery from the cooling period.

Another factor that may be associated with high sperm quality following cooling and dilution in $\mathrm{ACP}-117 \mathrm{c}$ is the modified protein types that exist in the epididymal fluid and the interaction of these proteins with the extender. Zambelli et al. (2010) reported that some proteins, also including albumin (P66), exist in the seminal plasma of domestic cats at higher concentrations than other proteins. These proteins act to facilitate the sperm membrane remodeling and the transport of lipophilic substances in order to protect the sperm cells and to avoid a premature acrosomal reaction. This may be associated with the ability of the epididymal sperm cells of domestic cats to remain viable following the cooling period, although further studies of the epididymal fluid protein profile of these animals, its correlation with sperm quality, and the site of action of those proteins are required. Also, despite the progress made with proteomic studies of sperm quality in cryopreservation processes, studies to determine how those proteins provide protection to sperm cells are still needed.

In order to minimize possible errors inherent of subjective sperm evaluation, computerized analysis has been implemented in research on various species, which has provided more reliable evaluations of the data obtained and allowed advances in animal reproduction (Arruda et al. (2011). In this research, it could be verified in computer analysis that ACP-117c provided a sperm percentage with curvilinear speed lower than Tris. This is a very relevant result considering that the higher the percentage of sperm presenting a circular path, the smaller the chance that these cells reach and fertilize the oocyte.
According to Muller et al. (2012), for semen samples to be considered morphologically normal, it is necessary that they contain over $60 \%$ of normal cells. Thus, samples of all groups evaluated in this study had a percentage of normal cells above the minimum established, characterizing them as normospermic. As in the research developed by Emerenciano et al. (2013), in the fresh groups for both extenders, the percentage of sperm with normal morphology remained above $70 \%$ and even after cooling periods, epididymal sperm were able to maintain their morphological structure viable $(>70 \%)$ in both tested extenders.

\section{CONCLUSION}

The ACP-117c extender may be successfully used to recover cat sperm cells from epididymides that have been cooled for up to 4 hours, which creates new possibilities for applying reproductive biotechnologies to cat species and may contribute to the conservation of endangered cats in the future.

\section{ACKNOWLEDGEMENTS}

The National Council for Scientific and Technological Development (CNPq) through individual research grants to LDMS (grant number 305420/2013-5), the Brazilian Federal Agency for the Support and Evaluation of Graduate Education (CAPES) and the Ceará State Support for Scientific and Technological Development Foundation (FUNCAP).

\section{REFERENCES}

ARRUDA, R.P.; CELEGHINI, E.C.C.; ALONSO, M.A. et al. Métodos de avaliação da morfologia e função espermática: momento atual e desafios futuros. Rev. Bras. Reprod. Anim., v.35, p.145-151, 2011.

AXNÉR, E.; LINDE-FORSBERG, C. Evaluación y recolección de sêmen, e inseminación artificial en el gato. Int. Vet. Inf. Serv., 2003. Disponível em: $<$ http://www.unrealragdolls.com/castracion.pdf $>$. Acessado em: 15 jun. 2014.

BARROS, T.B.; TONIOLLI, R. Uso potencial da água de coco na tecnologia de sêmen. Rev. Bras. Reprod. Anim., v.35, p.400-407, 2011. 
BOOTHE, H.W. Testículos e epidídimos. In: SLATTER, D.H. (Ed.). Manual de cirurgia de pequenos animais. Barueri: Manole, 2007. p.1521-1530.

COCCHIA, N.; CIANI, F.; EL-RASS, R. et al. Cryopreservation of feline epididymal spermatozoa from dead and alive animals and its use assisted reproduction. Zygote, v.18, p.1-8, 2009.

CORTOPASSI, S.R.G.; FANTONI, D.T. Medicação pré-anestésica. In: FANTONI, D.T.; CORTOPASSI, S.R.G. (Eds.). Anestesia em cães e gatos. São Paulo: Roca, 2009. p.217-227.

EMERENCIANO, K.D.M.; LIMA, G.L.; PEIXOTO, G.C.X. et al. Recuperação de espermatozoides epididimários de gatos domésticos (Felis catus) utilizando soluções à base de tris ou água de coco em pó. Acta Vet. Bras., v.7, p.148-153, 2013.

GOSDEN, R. Cryopreservation: a cold look at technology for fertility preservation. Fertil. Steril., v.96, p.264-268, 2011.

HERMANSSON, U.; AXNÉR, E. Epididymal and ejaculated cat spermatozoa are resistant to cold shock but egg yolk promotes sperm longevity during cold storage at

$4^{\circ} \mathrm{C}$. Theriogenology, v.67, p.1239-1248, 2007.

MAGALHÃES， L.C.O.; MELO-OÑA， C.M.; SUDANO, M.J. et al. Preservation of wild feline semen by freeze-drying: experimental model. Anim. Reprod. Sci., v.9, p.201-204, 2012.

MARTINEZ-PASTOR， F.; MACIAS， V.G.; ALVAREZ, M. et al. Comparison of two methods for obtaining spermatozoa from the cauda epididymis of Iberian red deer. Theriogenology, v.65, p.471-485, 2006.

MONTEIRO, G.A.; FREITAS-DELL'AQUA, C.P.; GUASTI, P.N. et al. Comparison of apoptotic cells between cryopreserved ejaculated sperm and epididymal sperm in stallions. $J$. Equine Vet. Sci., v.33, p.552-556, 2013.

MOTA FILHO, A.C.M.; SILVA, H.V.R.; NUNES, T.G.P. et al. Cryopreservation of canine epididymal sperm using ACP-106c and Tris. Cryobiology, v.69, p.17-21, 2014.
MULLER, G.; MARTINO-ANDRADE, A.J.; SANTOS, A.S. et al. Testicular testosterone: estradiol ratio in domestic cats and its relationship to spermatogenesis and epididymal sperm morphology. Theriogenology, v.78, p.1224-1234, 2012.

NUNES, J.F. (Ed.). Biotécnicas aplicadas à reprodução de pequenos ruminantes. Fortaleza: Tecnograf, 2010. 208p.

OLIVEIRA, K.G.; MIRANDA, A.S.; LEÃO, D.L. et al. Semen coagulum liquefaction, sperm activation and cryopreservation of capuchin monkey (Cebus apella) sêmen in coconut water solution (CWS) and Tes-tris. Anim. Reprod. Sci., v.123, p.75-80, 2011.

PRADIEE, J.; ESTESO, M.C.; CASTAÑO, C. et al. Cryopreservation of epididymal sperm from ibexes (Capra pyrenaica) using short equilibration time with glycerol. Theriogenology, v.82, p.525-528, 2014.

SILVA, A.R.; CARDOSO, R.C.S.; UCHOA, D.C.; SILVA, L.D.M. Effect of tris-buffer, egg yolk and glycerol on canine sêmen freezing. Vet. J., v.164, p.244-246, 2002.

SILVA, M.A.; PEIXOTO, G.C.X.; SANTOS, E.A.A. et al. Recovery and cryopreservation of epididymal sperm from agouti (Dasiprocta aguti) using powdered coconut water (ACP109c) and tris extenders. Theriogenology, v.76, p.1084-1089, 2011.

SILVA, T.F.P.; ACKERMANN, C.L.; SILVA, L.D.M. Desafios para o desenvolvimento da tecnologia da criopreservação de sêmen felino. Ciênc. Anim., v.22, p.143-160, 2012.

TEBET, J.M.; MARTINS, M.I.M.; CHIRINEA, V.H. et al. Cryopreservation effects on domestic cat epididymal versus electroejaculated spermatozoa. Theriogenology, v.66, p.1629$1632,2006$.

UCHOA, D.C.; SILVA, A.R.; CARDOSO, R.C.S. et al. Conservação do sêmen canino a $37^{\circ} \mathrm{C}$ em diluentes à base de água de coco. Cienc. Rural, v.32, p.91-95, 2002.

UCHOA, D.C.; SILVA, T.F.P.; CARDOSO, J.F.S. et al. Favoring the birth of female puppies after artificial insemination using chilled sêmen diluited with powdered coconut water (ACP106c). Theriogenology, v.77, p.1959-1963, 2012. 
VALADÃO, C.A.A. Anestésicos dissociativos. In: FANTONI, D.T.; CORTOPASSI, S.R.G. (Eds.). Anestesia em cães e gatos. São Paulo: Roca, 2009. p.237-245.

VERNOCCHI, V.; MORSELLI, M.G.; CONSIGLIO, A.L. et al. DNA fragmentation and sperm head morphometry in cat epididymal spermatozoa. Theriogenology, v.82, p.982-987, 2014.

VIANA, F.A.B. (Ed.). Guia terapêutico veterinário. Lagoa Santa: Cem, 2007. 336p.

VILLAVERDE， A.I.S.B.; MELO, C.M.; MARTIN, I. et al. Comparison of efficiency between two artificial insemination methods using frozen-thawed semen in domestic cat (Felis catus): artificial insemination in domestic cats. Anim. Reprod. Sci., v.114, p.434-442, 2009.
VIVEIROS, A.T.M.; NASCIMENTO, A.F.; ORFÃO, L.H.; ISAÚ, Z.A. Motility and fertility of the subtropical freshwater fish streaked prochilod (prochilodus lineatus) sperm cryopreserved in powdered coconut water. Theriogenology, v.74, p.551-556, 2010.

ZAMBELLI, D.; RACCAGNI, R.; CUNTO, M. et al. Sperm evaluation and biochemical characterization of cat seminal plasma collected by electroejaculation and urethral catheterization. Theriogenology, v.74, p.1396-1402, 2010. 